\title{
Myocardium Neutrophil Infiltration in Rat Model with Acute Myocardial Infarction Treated by Ramipril
}

\author{
Biomechy Oktomalioputri ${ }^{1}{ }^{*}$, Meutia Savitri' ${ }^{1}$, Dwisari Dillasamola ${ }^{2}$, Noverial $^{1}$
}

Biomechy Oktomalioputri ${ }^{1, *}$, Meutia Savitri1, Dwisari Dillasamola², Noverial ${ }^{1}$

'Medical Faculty Universitas Andalas, INDONESIA. ${ }^{2}$ Pharmacy Faculty Universitas Andalas, INDONESIA.

\section{Correspondence}

\section{Biomechy Oktomalioputri}

Medical Faculty Universitas Andalas, INDONESIA.

E-mail: biomechyoktomalioputri@med.unand. ac.id

History

- Submission Date: 05-02-2021;

- Review completed: 28-03-2021;

- Accepted Date: 06-04-2021.

DOI : 10.5530/pj.2021.13.144

Article Available online

http://www.phcogj.com/v13/i5

Copyright

(C) 2021 Phcogj.Com. This is an openaccess article distributed under the terms of the Creative Commons Attribution 4.0 International license.

\begin{abstract}
Introduction: Acute myocardial infarction (AMI) is a cardiovascular disease that attacks myocardial cells due to long-standing ischemia. In AMI there is neutrophil infiltration associated with the prognosis of the disease. One of the initial therapies for AMI is ACE inhibitors. Objective: To determine myocardial neutrophil infiltration In rat model with acute myocardial infarction which is given ramipril as an Ace inhibitor. Method: This research is an experimental study using the Post Test Only Control Group study design. This study used 24 experimental rats which were divided into 3 treatment groups. Data were analyzed using the One Way ANOVA test and the Least Significant Differences test. Results: The results obtained were the mean number of neutrophils in the $\mathrm{K}(-)$ group was 1.83 , the $\mathrm{K}(+)$ group was 22.67 , and the successive treatment group was 4,17 . Significant differences were obtained between the $K(+)$ group and the treatment group where the $p$ value was $0.001(p<0.05)$. Conclusion: There is an effect of $4 \mathrm{mg} / \mathrm{kg}$ BW ACE Inhibitor ramipril and on the number of myocardial neutrophils of rats with AMI. Keywords: Neutrophils, Acute Myocardial Infarction (AMI), ACE Inhibitors, Ramipril
\end{abstract}

\section{INTRODUCTION}

Cardiovascular disease is a non-communicable disease that affects many human populations in the world. According to the World Health Organization (WHO) in 2015, ischemic heart disease is the number one killer in the world with a percentage of $15.5 \%$ of 56 million people who died in 2015. The incidence of Acute Myocardial Infarction (AMI) in the United States is about one million people with the death of around 450,000 sufferers every year ${ }^{1}$ Indonesia ranks $32 \mathrm{nd}$ in the country with the highest mortality rate due to cardiovascular disease, which is 371 per 100,000 population per year. ${ }^{2}$ Acute Coronary Syndrome (ACS) is a major cardiovascular disease because it causes high rates of hospital treatment and mortality, one of the main manifestations is AMI. ${ }^{3}$

In Indonesia, cases of myocardial infarction are increasingly being found due to significant lifestyle changes. Although there is no definitive epidemiological data, morbidity and mortality rates tend to increase. ${ }^{4}$ AMI ranks 9th most inpatient diseases in RSUP Dr. M. Djamil Padang in 2016, as many as 504 cases. $^{5}$

Myocardial infarction is a cardiovascular disease that attacks myocardial cells due to longstanding ischemia. ${ }^{6}$ This disease is an advanced manifestation of acute Coronary Heart Disease (CHD). Myocardial infarction is a disease caused by a decrease in blood supply due to critical narrowing of the coronary arteries due to atherosclerosis or total blockage of the arteries by embolus or thrombus. When atherosclerotic plaques rupture or tear, a thrombosis process occurs, namely thrombus formation which causes total coronary artery occlusion and myocardial cell necrosis. ${ }^{7}$ Decreased coronary blood flow can also be caused by shock or bleeding resulting in an imbalance between the supply and oxygen demand of the heart. AMI is another manifestation of coronary heart disease including unstable angina pectoris, AMI with or without ST-segment elevation. ${ }^{8}$

AMI will occur in neutrophil activation and aggregation to the ischemic area. Neutrophil infiltration will cause microthrombosis in the coronary arteries which will cause endothelial damage and aggravate AMI. The higher the number of neutrophils, the wider the myocardial muscle necrosis due to an AMI attack. An increase in the number of neutrophils after AMI is associated with the prognosis of the disease.,10 Patients with a significant increase in neutrophils have a higher risk of malignant arrhythmia, acute heart failure, cardiogenic shock and other acute complications. ${ }^{10,11}$

Several studies have shown that the area of lesions in the AMI is equivalent to the number of neutrophils in the circulation. ${ }^{12}$ When the inflammation is occurred, neutrophils in the circulation will migrate to the tissue so that neutrophil infiltration of the coronary plaque and infarcted myocardium will occur. ${ }^{13}$ This shows the correlation between neutrophils in circulation with neutrophils in tissues, but there is not much research that explains neutrophils infiltration in tissues.

One of anti-ischemic therapy for AMI is Angiotensin-Converting Enzyme Inhibitor (ACE-I). ACE-I is used as initial therapy to reduce the death rate of patients with post-infarction accompanied by impaired systolic heart function, with or without clinical symptoms of heart failure. The use of ACE-I is still limited to patients with these characteristics, although in patients with risk factors for CHD or who have been proven to suffer from CHD, several studies have estimated an antiatherogenic effect. ${ }^{3}$ This is considered the most suitable vasodilator for AMI patients because ACE-I inhibits the formation

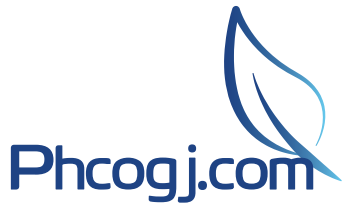

Cite this article: Oktomalioputri B, Savitri M, Dillasamola D, Noverial. Myocardium Neutrophil Infiltration in Rat Model with Acute Myocardial Infarction Treated by Ramipril. Pharmacogn J. 2021;13(5): 1116-1121. 
of Angiotensin II, thereby inhibiting vasoconstriction, decreasing aldosterone secretion and increasing bradykinin levels. ${ }^{14}$ Increased bradykinin levels will increase the production of Nitric Oxide (NO) and prostaglandins which have vasodilation, platelet anti-aggregation and antiproliferation effects. Increased $\mathrm{NO}$ will prevent endothelial dysfunction, thereby reducing the inflammatory reaction which will have an impact on decreasing the number of neutrophils. ${ }^{15}$

One of the ACE-I is ramipril which is given to patients with essential hypertension, stable chronic heart failure and myocardial infarction. On research using isoproterenol-induced AMI in rats, administration of ramipril as a pretreatment for 30 days reduced myocardial damage. The cardioprotective effect caused by ramipril is associated with oxidative stress inhibition which is one of the pathophysiologies of AMI. In this study mentioned, Ramipril reduced serum levels of Brain Natriuretic Peptide (BNP) after the occurrence of AMI. BNP serum level was reported to increase after the occurrence of AMI, so the study concluded that ramipril could be used as first-line therapy in hypertensive patients who have a high risk of heart damage ${ }^{16}$ But so far there have been no studies that discuss the effects of ramipril as pretreatment on myocardial histopathology of rats, specifically myocardial neutrophil infiltration which is one of the hallmarks of AMI.

Based on the description above, the researchers wanted to see whether ACE-I Ramipril given before AMI can affect the number of neutrophils in rats myocardium with AMI.

\section{MATERIAL AND METHOD}

\section{Research type}

This type of research is experimental research (True Experimental) with the approach of post-test only control group design that uses rats as research objects. This research group consisted of a negative control group, a positive control group and a treatment group.

\section{Rats model}

The population of this research is white rat (Rattus norvegicus) strain Wistar obtained from the Laboratory of Pharmacy, Andalas University. Criteria for inclusion of samples: white rats (Rattus norvegicus) strain Wistar healthy, rats aged 6-8 weeks at the time of sample selection, rat weight 150-200 grams, rats in living conditions and active movements, and rats have no anatomical defects. Sample exclusion criteria: die during the adaptation period, die when treated, rats have been used as an experimental animals before. The sample size was calculated using the Federer formula with a total of 24 rats.

\section{AMI model construction and ACE-I treatment}

Before treatment, rats were acclimatized for seven days and then divided into three groups: negative control (-), positive control (+), treatment. This study used isoproterenol at a dose of $85 \mathrm{mg} / \mathrm{kg} \mathrm{BW}$ subcutaneously for two consecutive days, which gives rise to myocardial infarction conditions in rats.

The administration ofACE inhibitors, ramipril, was carried out for seven days and isoproterenol was induced on the eighth and ninth-day treatment. Rats were given ramipril orally with a treatment dose of 4 $\mathrm{mg} / \mathrm{kg} \mathrm{BW}$. The negative control group rats were given $0.9 \% \mathrm{NaCl}$. Administration of ramipril is done orally (gavage) with a sonde.

\section{Sacrifice and measurement of neutrophil}

Rats were sacrificed by necropsy technique. The rats were first anesthetized with ketamine $75-100 \mathrm{mg} / \mathrm{kg} \mathrm{BW}$ given intraperitoneally. After the anesthesia worked, rats were placed on a table with their backs attached and each leg fixed with a needle. The incision started from the processus xiphoideus and then extended laterally. The rat diaphragm was opened so that the heart organ could be seen and separated from other organs. The heart was removed and immediately diffused with a cooled $0.9 \% \mathrm{NaCl}$ solution.

The heart was cut in the left ventricle with a thickness of 2-3 mm and incubated in a $2 \%$ TTC solution at temperature $37^{\circ} \mathrm{C}$ for 30 minutes and reversed every 15 minutes. The sections were put into formalin then made of paraffin blocks. The blocks are then painted with hematoxylin and eosin (HE). The sections were dehydrated, cleaned and covered with a glass cover. Data was obtained by counting neutrophils in three different fields of view with 400x magnification with a light microscope.

\section{Statistics}

Data analysis was performed using parametric statistical tests that met the requirements of normally distributed data and variants between the same groups. The neutrophil count results obtained were recorded, tabulated and analyzed with a computer program where the confidence interval was $95 \%$ and the significance was $0.05(p=0.05)$. To find out whether or not the distribution of the data obtained was normal, an analysis of normality was used using the Shapiro-Wilk test, while to determine the variance between groups homogeneity tests were performed with the statistical Levene test. The data were normally distributed and the variants were the same then One Way ANOVA test was performed to see the significance of each group. Then the Least Significant Differences (LSD) test was performed to see significant differences between groups. This research had passed the ethical review with a letter-number: 163/KEP/FK/2020.

\section{RESULT AND DISCUSSION}

The results of this study obtained 18 samples from 24 samples based on inclusion and exclusion criteria.

\section{Table 1: Experimental animal grouping.}

\begin{tabular}{ll}
\hline Group & Treatment \\
$\mathrm{K}(-)$ & Negative control (given only $0.9 \% \mathrm{NaCl}$ orally) \\
$\mathrm{K}(+)$ & $\begin{array}{l}\text { Positive control (given } 0.9 \% \mathrm{NaCl} \text { orally for seven days and } \\
\text { Isoproterenol was induced on the eighth and ninth day } \\
\text { treatment at a dose of } 85 \mathrm{mg} / \mathrm{kg} \mathrm{BW} \text { subcutaneously) }\end{array}$ \\
& $\begin{array}{l}\text { Treatment group (given ramipril orally with a treatment dose } \\
\text { of } 4 \mathrm{mg} / \mathrm{kgBW} \text { for seven days and isoproterenol was induced } \\
\text { on the eighth- and ninth-day treatment at a dose of } 85 \mathrm{mg} / \mathrm{kg} \\
\mathrm{PW}\end{array}$
\end{tabular}

Table 2: Mean neutrophil count results.

\begin{tabular}{cccc} 
Group & \multicolumn{3}{c}{ Total Neutrophils } \\
\cline { 2 - 4 } & $\begin{array}{c}\mathrm{K}(-) \\
(\mathrm{n}=6)\end{array}$ & $\begin{array}{c}\mathrm{K}(+) \\
(\mathrm{n}=6)\end{array}$ & $\begin{array}{c}\mathrm{P} . \\
(\mathrm{n}=6)\end{array}$ \\
\hline Rat 1 & 0 & 25 & 6 \\
Rat 2 & 3 & 20 & 3 \\
Rat 3 & 1 & 27 & 2 \\
Rat 4 & 2 & 20 & 4 \\
Rat 5 & 2 & 19 & 4 \\
Rat 6 & 3 & 25 & 6 \\
Average \pm SD & $1.83 \pm 1.169$ & $22.67 \pm 3.386$ & $4,17 \pm 1,602$
\end{tabular}

Table description

$\mathrm{n}$ : number of experimental animals

$\mathrm{K}(-)$ : negative control group

$\mathrm{K}(+)$ : positive control group

$\mathrm{P}$ : treatment group

Data is presented as Mean \pm SD

Difference data $(p)$ were declared significant if $p<0.05$ 
Myocardial preparations showed an increase in neutrophil infiltration was seen in the control group $(\mathrm{K}+)$ in which the rats were induced into acute myocardial infarction (figure 2 ). In the treatment group (P) there was a decrease in the number of neutrophils after being given ramipril (Figures 1-4; Table 2).

Based on the results in table 2, the mean number of neutrophils in the negative control group was 1.83 , the average number of neutrophils in the positive control group was 22.67 , and the mean number of neutrophils in the treatment group was 4,17 . The highest average number of neutrophils was in the positive control group and the lowest mean number of neutrophils is in the negative group.

Based on the results of statistical tests in this study, there was an increase in the number of neutrophils in the positive control group.

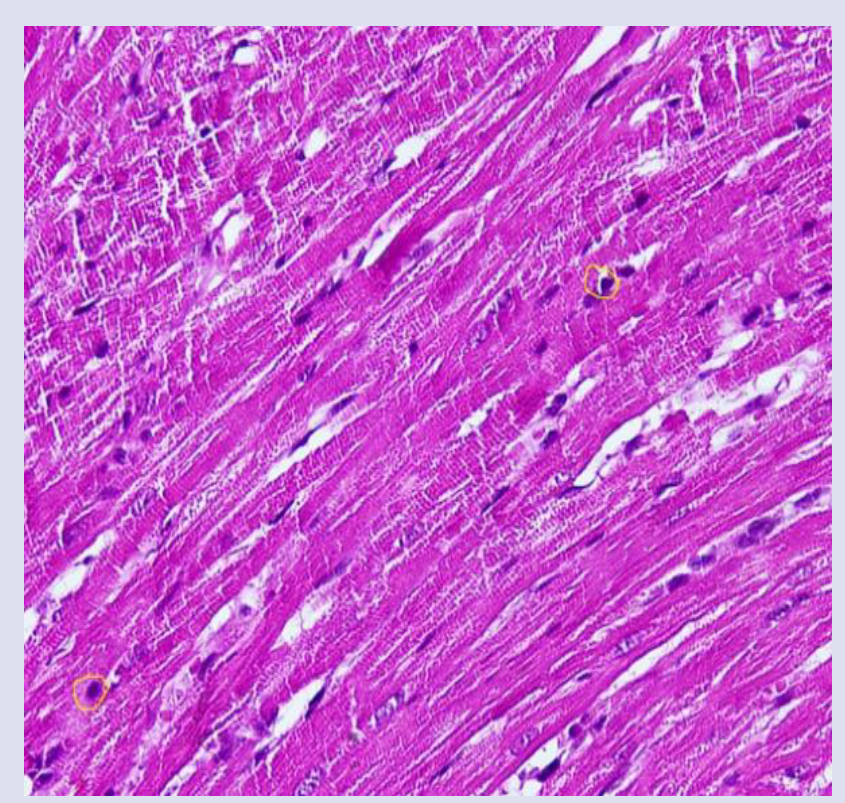

Figure 1: Myocardial Preparations in the Negative Control Group (Magnification 40x10). Neutrophils counted are those in the Yellow Circle.

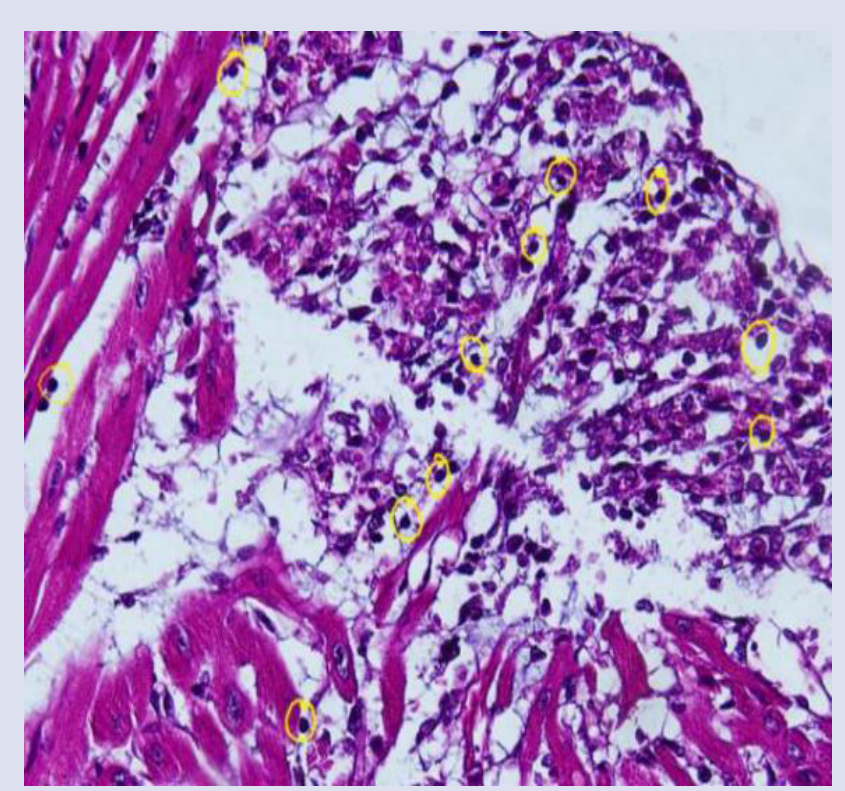

Figure 2: Myocardial Preparations in Positive Control Groups (Magnification 40x10). Neutrophils counted are those in the Yellow Circle.

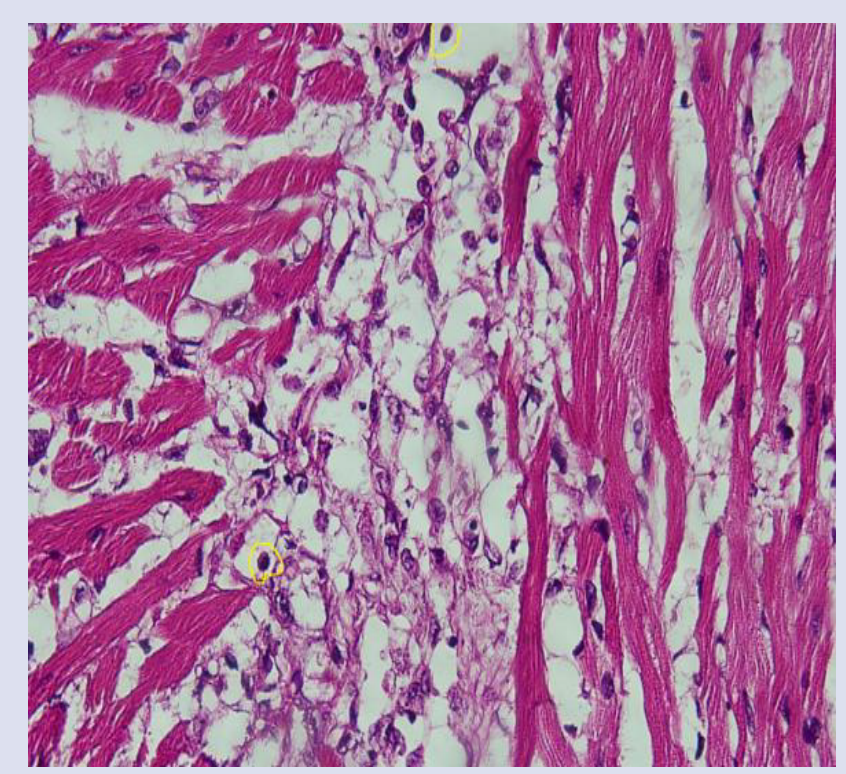

Figure 3: Myocardial preparations in Group P (magnification 40x10). Neutrophils counted are those in the Yellow Circle.

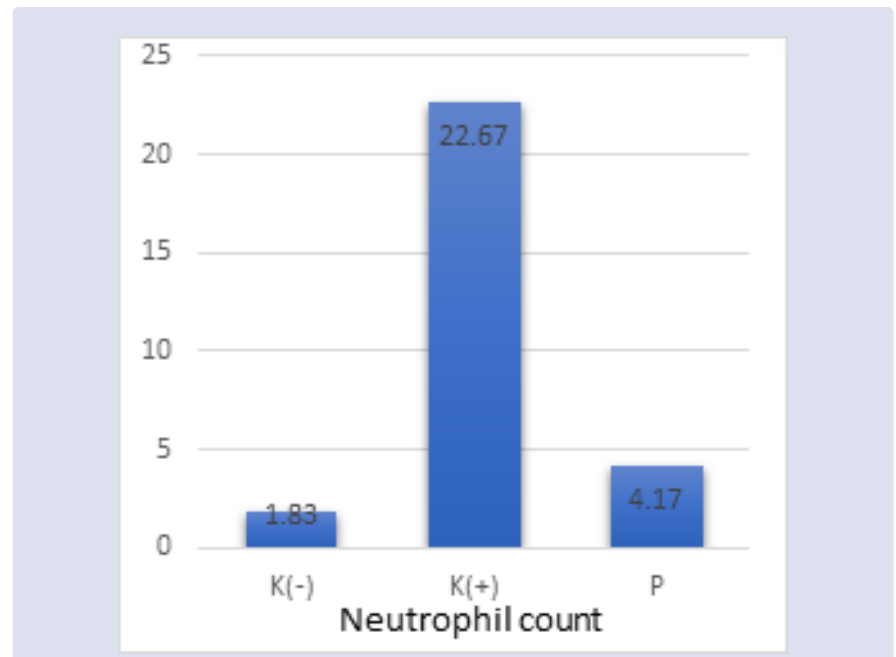

Figure 4: Diagram of Average neutrophil count of each group.

Statistical data analysis showed that there were significant differences between the positive control group and the negative control group. This was observed from the increasing number of neutrophils in the positive control group compared to the negative control group. This change was due to isoproterenol induction which causes inflammation and necrosis in myocardial rats. This data was by following per under the research of Heraldo Guedis Lobo Filho, et al. in 2011 there was a change in the increase in neutrophils in the heart of Wistar mice after administration of isoproterenol for two consecutive days. ${ }^{17}$

A review written by Syarifah Aisyah, et al. in 2018 showed that there was a study which explained that an intermediate dose of isoproterenol which is $85 \mathrm{mg} / \mathrm{kg}$ BW showed significant changes in biochemical parameters and moderate necrosis in the heart. Histological changes due to isoproterenol induction can be observed in the subendocardial layer, myocardial apex, left ventricle, papillary muscle and intraventricular septum. The Isoproterenol induction method has been widely used in studies that assess the cardioprotective effect of a drug on the prevention of myocardial damage in rats. ${ }^{18}$ 
Isoproterenol induction has been investigated to cause oxidative stress in the myocardial muscle causing infarction ${ }^{16}$ Isoproterenol can significantly increase ACE to increase angiotensin II. Angiotensin II will reduce NO production so that endothelial dysfunction will occur. Damaged tissue will trigger the emergence of inflammatory mediators such as cytokines and chemokines. High cumulation of cytokines and chemokines in the ischemic area will trigger the mobilization of neutrophils from the bone marrow to infarcted areas resulting in an increase in neutrophils in the myocardial system ${ }^{19,20}$

The calculation of neutrophil count in the treatment group statistically showed a significant difference to the positive control group. This shows that a ramipril dose of $4 \mathrm{~m} / \mathrm{kg}$ BW has an influence on the number of neutrophils in myocardial rats with AMI. Research that counts the number of neutrophils in myocardial rats given ramipril as a preventive treatment has not yet been found, but research shows that the increase in neutrophils is directly proportional to the severity of myocardial infarction. The higher the number of neutrophils, the wider myocardial damage caused by myocardial infarction ${ }^{12,21}$

A study conducted by Mohamed Saleem Thattakudian Sheik Uduman, et al. who assessed the cardioprotective effect of ramipril at a dose of 2 $\mathrm{mg} / \mathrm{kg} \mathrm{BW}$ in rats with cardiac ischemia found that normal myocardial tissue showed normal myofibril structure with striation, branching and branching forms with adjacent myofibrils. The ischemic group showed extensive myofibril degeneration, edema, focal hemorrhage, and leukocyte infiltration that indicated necrosis and in the group which is administered ramipril, it showed the structure of myofibril with striation, branched form and continued with adjacent myofibrils, which shape is similar to the normal control group. ${ }^{22}$ This study explains that there is a reduction in leukocyte infiltration in the group which administered ramipril so it can be concluded that a ramipril affects leukocyte infiltration, specifically neutrophils.

ACE-I can inhibit ACE thus inhibiting the change of angiotensin I to angiotensin II. The cardioprotective effect of ramipril is associated with the inhibition of oxidative stress-induced by angiotensin II. ACE-I can also increase bradykinin and NO to prevent endothelial dysfunction. This can reduce neutrophil infiltration in the myocardial due to the inflammatory response ${ }^{16}$

\section{CONCLUSIONS}

There are significant differences in the number of neutrophils between groups and there is an effect of giving ramipril $4 \mathrm{mg} / \mathrm{kg}$ BW to the number of myocardial neutrophils of AMI rats.

\section{ACKNOWLEDGMENT}

Thank you, the authors extend to all parties who have helped in the completion of this research.

\section{REFERENCES}

1. Lloyd-Jones D, Adams R, Carnethon M, De Simone G, Ferguson TB Flegal K, et al. Heart disease and stroke statistics--2009 update: a report from the American Heart Association Statistics Committee and Stroke Statistics Subcommittee. Circulation. 2009;119(3):e21-e181. https://doi.org/10.1161/CIRCULATIONAHA.108.191261

2. Jan S, Lee SW, Sawhney JP, Ong TK, Chin CT, Kim HS, et al. Catastrophic health expenditure on acute coronary events in Asia: a prospective study. Bull World Health Organ. 2016;94(3):193-200. https://doi.org/10.2471/BLT.15.158303

3. Irmalita, Juzar D, Andrianto, Setianto BY, Tobing DP, Firdaus I, et al. Perhimpunan Dokter Spesialis Kardiovaskular Indonesia. Pedoman Tatalaksana Sindrom Koroner Akut. $3^{\text {rd }}$ ed. Jakarta:Perhimpunan Dokter Spesialis Kardiovaskular Indonesia.Jakarta;2015.https:// inaheart.org/wpcontent/uploads/2021/07/Pedoman_tatalaksana_ Sindrom_Koroner_Akut_2015.pdf
4. World Health Organization. Global Status Reporton Non Communicable Diseases 2010. Ganeva: World Health Organization;2011.https:// www.who.int/nmh/publications/ncd_report_full_en.pdf

5. Pusat Informasi Manajemen RSUP Dr. M. Djamil Padang. Sepuluh Penyakit Terbanyak Rawat Inap di RSUP Dr. M. Djamil Padang tahun 2016.https://rsdjamil.co.id/laporan-rumah-sakit/

6. Thygesen K, Alpert JS, Jaffe AS, Simoons ML, Chaitman BR, White $H D$, et al. Third universal definition of myocardial infarction. Eur Heart J. 2012;33(20):2551-2567. https://doi.org/10.1093/eurheartj/ehs184

7. Storm JB, Libby P. Atherosclerosis. In: Lilly LS. Pathophysiology of Heart Disease: A Collaborative Project of Medical Students and Faculty. 5th ed. Baltimore: Wolters Kluwer; 2011. p.113-9

8. Muhadi, Trisnohadi H. Angina Pectorik Tak Stabil//nfark Miokard Akut Tanpa Elevasi ST. In: Setiati S, Alwi I, Sudoyo AW, SAM Idibrata M, Setiyohadi B, Syam AF, editors. IImu Penyakit Dalam Volume 2. $6^{\text {th }}$ Ed. Jakata: Interna Publishing; 2015. p.1451-3

9. Denktas AE, Anderson HV, McCarthy J, Smalling RW. Total ischemic time: the correct focus of attention for optimal ST-segment elevation myocardial infarction care. JACC Cardiovasc Interv. 2011;4(6):599604. https://doi.org/10.1016/j.jcin.2011.02.012

10. Betgem RP, de Waard GA, Nijveldt R, Beek AM, Escaned J, van Royen N. Intramyocardial haemorrhage after acute myocardial infarction. Nat Rev Cardiol. 2015;12(3):156-167. https://doi. org/10.1038/nrcardio.2014.188

11. Agacdiken A, Celikyurt U, Sahin T, Karauzum K, Vural A, Ural D. Neutrophil-to-lymphocyte ratio predicts response to cardiac resynchronization therapy. Med Sci Monit. 2013;19:373-377. https:// doi.org/10.12659/MSM.883915

12. Soehnlein O. Multiple roles for neutrophils in atherosclerosis Circ Res. 2012;110(6):875-888. https://doi.org/10.1161/ CIRCRESAHA.111.257535

13. Carbone F, Nencioni A, Mach F, Vuilleumier N, Montecucco F. Pathophysiological role of neutrophils in acute myocardial infarction. Thromb Haemost. 2013;110(3):501-514. https://doi.org/10.1160/ TH13-03-0211

14. Jackson E. Renin dan Angiotensin. In: Sulistia S, Gunawan G. Farmakologi dan Terapi. $5^{\text {th }}$ ed. Jakarta: FKUI Publishing Center; 2012. p.796-800

15. Guyton A, Hall J. Buku Ajar Fisiologi Kedokteran. $12^{\text {th }}$ ed. Singapore: Elsevier; 2014. p.266-9

16. Bayir Y, Cadirci E, Suleyman H, Halici Z, Keles MS. Effects of Lacidipine, Ramipril and Valsartan on Serum BNP Levels in Acute and Chronic Periods Following Isoproterenol-Induced Myocardial Infarction in Rats. Eurasian J Med. 2009;41(1):44-48. PMID: 25610063; PMCID: PMC4261647.https://doi.org/10.1007/s11010009-0080-y

17. Filho HGL, Ferreira NL, de Sousa RB, de Carvalho ER, Lobo PLD, Filho JGL. Experimental model of myocardial infarctioninduced by isoproterenol in rats. Rev Bras Cir Cardiovasc. 2011;26(3):469-76. https://doi.org/10.5935/1678-9741.20110024

18. Halim SASA, Ghafar NA, Jubri Z, Das S. Induction of Myocardial Infarction in Experimental Animals: A Review. J Clin Diagnostic Res. 2018; 12 (11): 1-5.https://doi.org/10.7860/JCDR/2018/36997.12221

19. Ma Y, Yabluchanskiy A, Lindsey ML. Neutrophil roles in left ventricular remodeling following myocardial infarction. Fibrogenesis Tissue Repair. 2013;6(1):11.https://doi.org/10.1186/1755-1536-6-11

20. Uduman MSTS, Reddy RB, Punuru P, Chakka G, Karunakaran G. Protective roles of Ramipril and Candesartan against myocardial ischemic reperfusion injury: A biochemical and transmission electron microscopical study. Adv Pharmacol Sci. 2016:1-8 https://doi. org/10.1155/2016/4608979 
21. Oncel RC, Ucar M, Karakas MS, Akdemir B, Yanikoglu A, Gulcan AR, et al. Relation of neutrophil-to-lymphocyte ratio with GRACE risk score to in-hospital cardiac events in patients with ST-segment elevated myocardial infarction. Clin Appl Thromb Hemost. 2015;21(4):383-8. https://doi.org/10.1177/1076029613505763
22. Sheik Uduman MST, Reddy RB, Punuru P, Chakka G, Karunakaran $\mathrm{G}$. Protective role of Ramipril and Candesartan against myocardial ischemic reperfusion injury: A biochemical and transmission electron microscopical study. Adv Pharmacol Sci. 2016; 2016: 1-7. https://doi. org/10.1155/2016/4608979

\section{GRAPHICAL ABSTRACT}
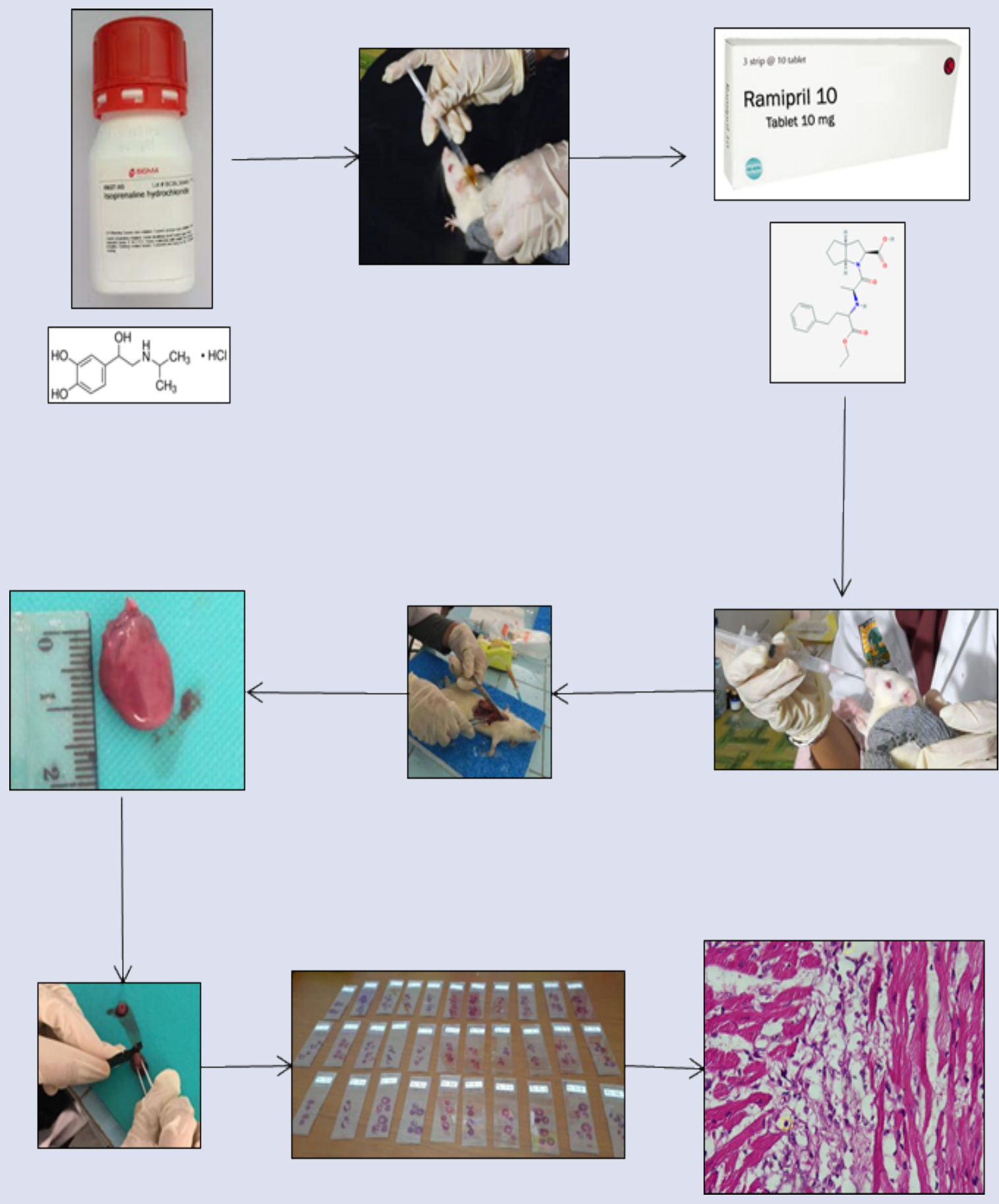


\section{SUMMARY}

ACE Inhibitor Ramipril is a treatment given to patients with essential hypertension, stable chronic heart failure and myocardial infarction. This research objective is to determine the effect of administration of ACE inhibitors to the number of neutrophils in myocardial rats with AMI since several studies have shown that the area of lesions in the Acute Myocardial Infarction is equivalent to the number of neutrophils in the circulation. Group I served as negative control (given $\mathrm{NaCl} 0,9 \%$ orally), Group II served as positive control (given $\mathrm{NaCl} 0,9 \%$ orally for seven days and Isoproterenol were induced on the eighth and ninth day at a dose of $85 \mathrm{mg} / \mathrm{kgbw}$ subcutaneously). Group III were given ramipril orally with a treatment dose of $4 \mathrm{mg} / \mathrm{kgBW}$ for seven days and isoproterenol was induced on the eighth and ninth day treatment at a dose of $85 \mathrm{mg} / \mathrm{kgBW}$ subcutaneously. The research data were processed using the One Way ANOVA test. The result showed that There are significant differences in the number of neutrophils between groups and there is an effect of giving ramipril $4 \mathrm{mg} / \mathrm{kgBW}$ to the number of myocardial neutrophils of $\mathrm{AMI}$ rats.

\section{ABOUT AUTHORS}

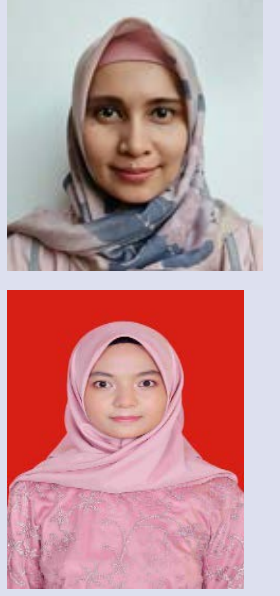

dr. Biomechy Oktomalioputri, M. Biomed : Born in Padang at 18 October 1983. Completed her education in Medicine Faculty in 2009 at Andalas University, then the Masters Program at Biomedical Science at Andalas University. Currently, she is a lecturer in the Histology Section of the Faculty of Medicine Andalas University. Her research interest in Histological science and biomolecular research.

Meutia Savitri: is an undergraduate student of the Faculty of Medicine, Andalas University. She is interested in biomolecular and histological science.

Dwisari Dillasamola, M.Farm, Apt : Currently as a lecturer in a functional position at the Faculty of Pharmacy, Andalas University. Graduated from the Faculty of Pharmacy, Andalas Pharmacy, Andalas University in 2011. Her research and expertise are in the field of Pharmacology-toxicology. Currently working as a lecturer in Pharmacology and Clinical Pharmacy at the Faculty of Pharmacy, Andalas University.

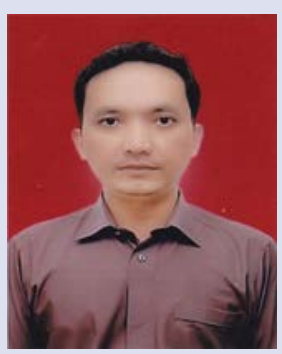

dr. Noverial, Sp.OT : Currently as a lecturer in a Medical Faculty, Andalas University. Completed his education in Medicine Faculty in 1994 at Andalas University and his Specialist in Orthopaedic and Traumatology in Hasanuddin University (2001). His research interest in biomedical and orthopedic sciences.

Cite this article: Oktomalioputri B, Savitri M, Dillasamola D, Noverial. Myocardium Neutrophil Infiltration in Rat Model with Acute Myocardial Infarction Treated by Ramipril. Pharmacogn J. 2021;13(5):1116-1121. 